\title{
PENGAMBILAN KEPUTUSAN ORANG TUA MENIKAHKAN DINI ANAK AKIBAT HAMIL DI LUAR NIKAH (Studi Kasus di Desa Kalangan Klego Boyolali)
}

\author{
${ }^{1}$ Yulindawati, ${ }^{2}$ Galih Fajar Fadillah, ${ }^{3}$ Anni Nurul Hidayati \\ 1,2Fakultas Ushuluddin dan Dakwah IAIN Surakarta \\ ${ }^{3}$ Fakultas Ekonomi Universitas Nahdlatul Ulama Surakarta \\ 1lyndhawati0@gmail.com, 2galihfajarf@gmail.com,3anniweasley@gmail.com
}

\section{Abstract}

The aim of this study is to describe the decision-making process of parents who marry their children at an early age due to pregnancy outside of marriage. This research methods with a case study approach, in which the researcher explains and describes the decision-making process of parents in overcoming the problems of pregnant children outside of marriage. The results showed that parents have a basis for decision making intuition, retionale, facts. The according to parents, marrying off their children is the best solution or alternative to solve the problems of pregnant children outside of marriage. Even though there are parents who want to have an abortion, after knowing the impact, they still choose to marry their child. Parents think that marrying off their children is the best decision even though children must marry at an early age. This was done to cover the family's disgrace because they didn't want their child to get pregnant without a husband and parents wanted the child to be responsible for the actions that had been done.

Keywords: Pregnant Outside of Marriage, Get Married Early, Decision Making

\section{Abstrak}

Tujuan penelitian ialah mengetahui gambaran proses pengambilan keputusan orang tua yang menikahkan anak usia dini akibat hamil diluar nikah. Pendekatan yang digunakan bersifat kualitatif dengan jenis studi kasus. Peneliti menjelaskan dan mendeskripsikan tentang proses pengambilan keputusan orang tua dalam mengatasi permasalahan anak hamil diluar nikah. Hasil penelitian menunjukan bahwa orang tua memiliki dasar pengambilan keputusan intuisi, rasional dan fakta. Keputusan Orang tua untuk menikahkan anaknya merupakan solusi atau alternatif terbaik guna menyelesaikan permasalahan anak hamil diluar nikah. Adapula beberapa orang tua awalnya berencana untuk melakukan aborsi akantetapi setelah mengetahui resiko yang harus diterima oleh anaknya sehingga menikahkan anak menjadi alternatif utama. Orang tua berpikir menikahkan anak merupakan keputusan terbaik meskipun anak harus menikah diusia dini. Hal tersebut dilakukan guna menutupi aib keluarga karena mereka tidak 
ingin anaknya hamil tanpa adanya suami dan orang tua ingin anak bertanggung jawab atas perbuatan yang sudah dilakukan.

Kata Kunci: Hamil Di luar Nikah, Menikah dini, Pengambilan Keputusan

\section{PENDAHULUAN}

Perkembangan usia anak remaja dikelompokkan dalam tahap perkembangan peralihan atau fase peralihan. Fase peralihan tersebut terdiri atas fase perkembangan anak menuju fase dewasa. Dengan kata lain remaja dapat memunculkan sikap sebagai seorang anak dapat pula meniru pemikiran orang dewasa. Fase peralihan ini menurut Hurlock (dalam Suhaida dkk, 2018) menyebut masa remaja sebagai masa yang memiliki banyak perubahan atau peralihan dari satu tahap ke tahap berikutnya yang meliputi beberapa aspek seperti, emosi, tubuh, minat, pola perilaku, dan juga penuh dengan masalah-masalah. Hal ini memperkuat bahwa perubahan pada masa remaja cukup kompleks sehingga perlu pengawasan dan pendampingan dari orang dewasa disekitarnya

Lebih lanjut Santrock (dalam Rahmawati \& Friska, 2017) mendefinnisikan remaja sebagai seorang individu yang memiliki keingintahuan dengan kecenderungan tidak pernah terpuaskan perihal seksualitas. Senada dengan pendapat sebelumnya Ajeng (dalam Rahmawati \& Friska, 2017) menjelaskan tentang resiko pengetahuan seks yang hanya setengah-setengah dengan cara mengakses internet dan melakukan eksplorasi sendiri melalui majalah, buku, dan film dewasa serta yang memaparkan kenikmatan hubungan seks tanpa mengajarkan tanggungjawab menjadi acuan remaja melakukan hubungan seks usia dini. Akibat yang ditanggung jika terus-terusan melakukan seks bebas adalah kehamilan tidak diinginkan, aborsi, tekanan psikologis dan pernikahan secara dadakan atau marride by accidental.

Remaja dengan kehamilan yang tidak dikehendaki berdampak tidak hanya bagi remaja yang bersangkutan, melainkan orang-orang terdekat, terlebih anggota keluarga. Manuaba (dalam Hastuti \& Fajaria, 2016) menjelaskan resiko bagi remaja dengan kehamilan yang tidak diinginkan yakni perasaan berdosa, perasaan bersalah terhadap keluarga, malu, cemas melihat kondisi kehamilan yang kian membesar. Lebih lanjut remaja merasa tertekan ketika keluarga dan orang-orang terdekat mengecam perbuatan tersebut sebagai tindakan amoral dalam pergaulan, melanggar norma masyarakat dan agama

Kehamilan tidak diinginkan (KTD) pada remaja perempuan yang kemudian memaksa orang tua melakukan pernikahan dini. Dengan menikahan remaja yang hamil diluar nikah dapat menutupi rasa malu keluarga dan dianggap cara paling efektif menyelesaikan permasalahan KTD (Aprianti dkk, 2018). United Nations Fund for Population acivities (UNFPA) sebagai organisasi PBB bidang populasi, 
memperkirakan bahwa pada tahun 2020 terjadi peningkatan pernikahan usia dini dan setiap tahunnya mencapai 14,2 juta, kemudian pada tahun 2030 diperkirakan pertahunnya mencapai 15,1 juta. Pada tahun 2010, satu dari tiga wanita atau 67 juta perempuan yang berusia 20-24 tahun menikah sebelum mereka berusia 18 tahun. Paling banyak pernikahan dini berlangsung di negara-negara berkembang termasuk Indonesia (Kanella dkk, 2017).

Pada kasus kehamilan diluar nikah umumnya adalah menikahkan anak meskipun masih di bawah umur. Seperti hasil penelitian Aprianti dkk (2018) menunjukan pilihan atau respon orang tua dalam menghadapi permasalahan KTD adalah dengan menikahkan remaja. Walaupun terdapat orang tua yang meminta untuk melakukan aborsi, tetapi setelah gagal informan tetap dinikahkan. Alasan dengan menikahan remaja yang KTD dapat menutupi rasa malu keluarga dan dianggap cara paling efekif menyelesaikan permaslahan KTD. Hal tersebut juga diperkuat oleh penelitian Sari dan Dinie (2017) dimana hasil penelitian menunjukan bahwa pernikahan karena hamil di luar nikah merupakan suatu jalan keluar yang dipilih keluarga untuk menyelesaikan permasalahan yang dialami remaja putri yang mengalami kehamilan pranikah. Meskipun terdapat dampak yang ditimbulkan dari keputusan remaja untuk melakukan pernikahan guna menutupi kehamilannya.

Keputusan menikahkan anak yang hamil diluar merupakan keputusan yang sulit bagi orang tua, termasuk orang tua yang ada di Desa Kalangan, Klego, Boyolali. Hasil wawancara pada tanggal 14 Mei 2020 dengan Bapak X, salah satu orang yang menikahkan dini anaknya menyebutkan alasan menikahkah anaknya factor untuk menutupi aib keluarga. Menurutnya pengambilan keputusan untuk menikahkan anak diusia dini merupakan solusi yang harus diambil karena kondisi anak yang hamil diluar nikah. Walaupun ia mengetahui dampak dari pernikahan dini tersebut akan merenggut masa depan anak yang harus putus sekolah. Namun ia tidak ingin anaknya mengandung tanpa adanya suami. Oleh sebab itu guna menutupi aib serta kehamilan anak tersebut orang tua terpaksa mengambil keputusan untuk menikahkan anak diusia dini. Selain hal tersebut orang tua juga beranggapan menikahkan anak dengan kasus kehamilan di luar nikah dirasa dapat melatih anak untuk belajar bertanggungjawab atas perbuatan yang telah dilakukannya.

Berdasarkan latar belakang diatas maka tujuan penelitian ini adalah untuk mengetahui gambaran proses pengambilan keputusan orang tua yang menikahkan anak usia dini akibat hamil diluar nikah.

\section{METODE PENELITIAN}

Jenis penelitian ini adalah penelitian kulitatif dengan pendekatan studi Kasus. Penelitian ini menggunakan metode kualitatif dengan pendekatan studi kasus. Creswell (dalam Raco, 2010) mendefinisikan studi kasus sebagai suatu 
eksplorasi dari sistem-sistem yang terkait bounded sytem atau kasus. Suatu kasus menarik untuk diteliti karena corak khas kasus tersebut yang memiliki arti pada orang lain, minimal bagi peneliti.

Subjek dalam penelitian ini adalah lima orang tua yang dipilih melalui purposive sampling. Teknik pengumpulan data menggunakan wawancara, observasi dan dokumentasi. Analisis data menggunakan analisis interaktif dengan melakukan pengumpulan data, reduksi data, penyajian data, menarik kesimpulan dan keabsahan data menggunakan triangulasi sumber.

\section{HASIL PENELITIAN}

\section{Dasar pengambilan Keputusan}

Dalam pengambilan keputusan terdapat dasar pengambilan keputusan orang tua menikahkan dini anak akibat hamil di luar nikah. Dari hasil wawancara dengan kelima subjek yaitu orang tua yang menikahkan anak di usia dini. Berikut merupakan tabel kesimpulan dasar-dasar pengambilan keputusan orang tua menikhakan anak di usia dini di Desa Kalangan Kecamatan Klego Kabupaten Boyolali.

Tabel 1. Dasar Pengambilan Keputusan

\begin{tabular}{|c|c|c|c|c|c|}
\hline \multirow{2}{*}{$\begin{array}{l}\text { Dasar } \\
\text { Pengambil- } \\
\text { an } \\
\text { Keputusan }\end{array}$} & \multicolumn{5}{|c|}{ Nama Subjek (Inisial) } \\
\hline & $\begin{array}{l}\text { Keluarga } \\
\text { AS }\end{array}$ & $\begin{array}{l}\text { Keluarga } \\
\text { SI }\end{array}$ & Keluarga T & $\begin{array}{l}\text { Keluarga } \\
\text { SM }\end{array}$ & $\begin{array}{l}\text { Keluarga } \\
\text { F }\end{array}$ \\
\hline Intuisi & $\begin{array}{l}\text { Perasaan } \\
\text { orang tua } \\
\text { yang } \\
\text { memikir- } \\
\text { kan } \\
\text { sendiri. }\end{array}$ & $\begin{array}{l}\text { Perasaan } \\
\text { orang tua } \\
\text { yang } \\
\text { memikir- } \\
\text { kan } \\
\text { sendiri. }\end{array}$ & $\begin{array}{l}\text { Perasaan } \\
\text { subjek } \\
\text { yang } \\
\text { memikir- } \\
\text { kan } \\
\text { sendiri. }\end{array}$ & $\begin{array}{l}\text { Memikir- } \\
\text { kan secara } \\
\text { kekeluarga } \\
\text {-an dari } \\
\text { dua belah } \\
\text { pihak. }\end{array}$ & $\begin{array}{l}\text { Penyelesa } \\
\text { ian secara } \\
\text { kekeluar- } \\
\text { gaan dari } \\
\text { dua belah } \\
\text { pihak. }\end{array}$ \\
\hline Rasional & $\begin{array}{l}\text { Mengetah } \\
\text { ui resiko } \\
\text { dan } \\
\text { konsekuen } \\
\text { si. }\end{array}$ & $\begin{array}{l}\text { Mengetah } \\
\text { ui resiko } \\
\text { dan } \\
\text { konsekuen } \\
\text { si. }\end{array}$ & $\begin{array}{l}\text { Mengetah } \\
\text { ui resiko } \\
\text { dan } \\
\text { konsekuen } \\
\text { si. }\end{array}$ & $\begin{array}{l}\text { Mengetah } \\
\text { ui resiko } \\
\text { dan } \\
\text { konsekuen } \\
\text { si. }\end{array}$ & $\begin{array}{l}\text { Mengetah } \\
\text { ui resiko } \\
\text { dan } \\
\text { konsekun } \\
\text { si. }\end{array}$ \\
\hline Fakta & $\begin{array}{l}\text { Keadaan } \\
\text { anak } \\
\text { subjek } \\
\text { yang } \\
\text { sudah } \\
\text { hamil. }\end{array}$ & $\begin{array}{l}\text { Keadaan } \\
\text { anak } \\
\text { subjek } \\
\text { yang } \\
\text { sudah } \\
\text { hamil. }\end{array}$ & $\begin{array}{l}\text { Keadaan } \\
\text { anak } \\
\text { subjek } \\
\text { yang } \\
\text { sudah } \\
\text { hamil. }\end{array}$ & $\begin{array}{l}\text { Keadaan } \\
\text { anak } \\
\text { subjek } \\
\text { yang } \\
\text { sudah } \\
\text { hamil. }\end{array}$ & $\begin{array}{l}\text { Keadaan } \\
\text { anak } \\
\text { subjek } \\
\text { yang } \\
\text { sudah } \\
\text { hamil. }\end{array}$ \\
\hline Pengalaman & - & - & - & - & - \\
\hline
\end{tabular}




\begin{tabular}{|l|l|l|l|l|l|}
\hline Wewenang & - & - & - & - & - \\
\hline
\end{tabular}

Berdasarkan tabel diatas subjek keluarga AS, SI dan T memiliki dasar pengambilan keputusan berdasarkan intuisi, rasional dan fakta. sedangkan subjek keluarga SM dan F memiliki dasar pengambilan keputusan berdasarkan rasional dan fakta.

\section{Proses Pengambilan Keputusan}

Dari hasil wawancara ditemukan bahwa sebelum mengambil keputusan orang tua mencari informasi terkait kebenaran dari permasalahan yang mereka hadapi. Kemudian semua subjek yaitu keluarga AS, keluarga SI, keluarga T, keluarga SM dan keluarga F memilih untuk menikahkan anak. Proses pengambilan keputusan yang dilakukan orang tua untuk menyelesaikan permasalahan anak hamil diluar nikah yaitu dengan cara merancang solusi atau alternatif kemudian memilih yang terbaik untuk menyelesaikan masalah. Dimana dalam penelitian ini ditemukan terdapat orang tua yaitu subjek AS yang berencana untuk mengaborsi anak, akan tetapi setelah mengetahui dampak dari keputusan tersebut Subjek AS memilih untuk menikahkan anak. Sedangkan keluarga SI, T, SM dan S merancang untuk menikahkan anak. Bagi kelima subjek Menikahkan anak merupakan solusi atau alternatif terbaik untuk menyelesaikan permasalahan anak hamil diluar nikah.

\section{PEMBAHASAN}

Dari hasil penelitian yang telah dilakukan bahwa lima subjek mengalami permasalahan yaitu anak hamil di luar nikah. Menurut Marantika (2015) Hamil di luar nikah adalah suatu pernikahan yang telah didahului oleh kehamilan pengantin wanita sebelum melakukan akad nikah.

Menurut Marni (dalam Amalia, 2015) terdapat dua hal yang bisa dilakukan oleh remaja ketika ia hamil di luar nikah, yaitu dengan mempertahankan kehamilan dan mengakhiri kehamilan (aborsi). Hal tersebut sama dengan tindakan yang harus dilakukan oleh orang tua menikahkan anak atau menyuruh anak melakukan aborsi. Kehamilan di luar nikah tersebut juga akan menimbulakan remaja dan orang tua dalam situasi tertekan.

Terjadinya hamil di luar nikah, karena anak melakukan hubungan yang melanggar norma, kebanyakan memaksa anak dan orang tua untuk melakukan pernikahan dini. Hal tersebut dilakukan guna memperjelas status anak yang dikandung. Pernikahan tersebut memaksa anak bertanggung jawab untuk berperan sebagai suami istri serta menjadi ayah dan ibu, sehingga hal tersebut akan berdampak pada penuaan dini, karena anak belum siap secara lahir dan 
batin. disamping itu, dengan kehamilan di luar nikah dan ketakutan pada orang tua akan mendorong terjadinya pernikahan dini. (Mubasyaroh, 2016)

Pada kasus kehamilan diluar nikah umumnya adalah menikahkan anak meskipun masih di bawah umur. Seperti hasil penelitian Aprianti dkk (2018) menunjukan pilihan atau respon orang tua dalam menghadapi permasalahan KTD adalah dengan menikahkan remaja. Walaupun terdapat orang tua yang meminta untuk melakukan aborsi, tetapi setelah gagal anak tetap dinikahkan. Alasan dengan menikahan remaja yang KTD dapat menutupi rasa malu keluarga dan dianggap cara paling efekif menyelesaikan permaslahan KTD.

Dalam kasus anak hamil diluar nikah mau tidak mau orang tua harus mengambil sebuah keputusan untuk menyelesaikan permasalahan tersebut. Menurut Atmosudirjo (dalam Tyas \& Siti, 2018: 81) pengambilan keputusan merupakan suatu proses pemikiran tentang suatu masalah atau problem, untuk menjawab pertanyaan apa yang harus diperbuat guna mengatasi permasalahan tersebut, dan menjadikan pilihan pada salah satu alternatif tertentu. Bagi kelima subyek menikahkan anak merupakan solusi terbaik untuk mengatasi permasalahan anak hamil di luar nikah meskipun anak menikah diusia dini.

Pernikahan dini menurut Syamsul (dalam Junaidi dkk, 2019) menyatakan bahwa pernikahan dini adalah sebuah ikatan yang salah satu kedua pasangan berusia 18 tahun. Jadi sebuah perkawinan disebut, jika keduanya atau salah satu pasangan masih berusia dibawah 19 tahun untuk remaja laki-laki dan 16 tahun untuk perempuan. Jadi dalam hal ini disebut pernikahan dini jika salah satu atau keduanya berada dibawah usia 18 tahun.

Keputusan menikahkan anak di usia dini merupakan keputusan yang sulit bagi orang tua, karena hal tersebut akan menimbulkan berbagai dampak. Menurut Setiyaningrum (dalam Yanti dkk, 2018) dampak tersebut diantaranya yaitu kematangan psikologis yang belum tercapai, remaja putus sekolah, ditinjau dari segi kesehatan menikah muda akan berdampak pada meningkatnya kematian bayi dan ibu, resiko komplikasi kehamilan, persalinan dan nifas. Kemudian akan berdampak pada tingkat perceraian yang tinggi dan remaja belum mampu untuk memenuhi kehidupan sehari-hari.

Karena menikahkan anak di usia dini merupakan keputusan yang sulit maka dari itu, akan melalui berbagai tahapan agar mendapat keputusan yang baik. Dalam proses pengambilan keputusan tidak terlepas dari dasar pengambilan keputusan. Dasar pengambilan keputusan menikahkan dini anak Menurut Goerge R. Terry (dalam Syamsi, 1995) terdapat lima dasar pengambilan keputusan antara lain sebagai berikut:

1. Intuisi

Keputusan yang diambil berdasarkan intuisi atau perasaan memiliki sifat subjektif, sehingga mudah terkena sugesti, pengaruh luar dan faktor kejiwaan (Syamsi: 1995). Penelitian ini mengungkap bahwa subyek yang memiliki dasar 
pengambilan intuisi yaitu Subyek AS, SI dan T, karena dari hasil wawancara menunjukan bahwa saat mengambil keputusan menikahkan dengan pemikiran mereka sendiri dengan perasaan berharap agar masalah tersebut dapat terselesaikan.

2. Rasional

Menurut Syamsi (1995) Keputusan yang diambil berdasarkan rasional banyak berkaitan dengan pertimbangan dari segi daya guna. Keputusan yang dibuat berdasarkan pertimbangan yang rasional lebih bersifat objektif. Dilihat dari pernyataan subyek ketika wawancara kelima subyek penelitian memiliki dasar pengambilan keputusan rasional. Dimana kelima subyek tersebut sebelum pengambilan keputusan mempertimbangkan resiko dan mengetahui konseuknsi dari keputusan yang akan diambil.

Hal tersebut diketahui dari hasil wawancara terhadap subjek saat pengambilan keputusan terdapat subjek memikirkan masa depan anak akibat anak di keluarkan dari sekolah, malu jika tetangga mengetahui anak hamil tanpa suami dan orang tua juga memikirkan resiko jika menikahkan anak di usia dini secara pengetahuan anak belum dewasa, belum memikirkan hidup berumah tangga kedepannya seperti apa dan anak belum mampu memenuhi kehidupan sehari-hari.

3. Fakta

Pengambilan keputusan sebaiknya itu didukung oleh sejumlah fakta yang memadai. Istilah fakta disini perlu dikaitkan dengan istilah data dan informasi (Syamsi, 1995). Dalam hal ini maka sebelum pengambilan keputusan orang tua diharapkan mencari fakta dari permasalahannya. Sehingga dalam penelitian ini dapat diungkap bahwa kelima subyek memiliki dasar pengambilan keputusan fakta. Faktanya keadaan anak yang hamil diluar nikah. Maka dari itu sebelum pengambilan keputusan menikahkan anak mereka mencari informasi terkait siapa yang telah mengahamili anaknya dan mencari kebenaran dari permasalahan tersebut. Dimana dari hasil wawancara diketahui sebelum mengetahui kebenarannya orang tua mencari informasi dari anak tentang kebenaran dari permasalahan yang dihadapi dan bertanya siapa yang telah mengahamili anaknya tersebut.

4. Pengalaman

Keputusan yang berdasarkan pengalaman sangat bermanfaat bagi pengetahuan prakrtis. Pengalaman dan kemampuan seseorang untuk memprakirakan apa yang menjadi latar belakang masalah dan bagaimana arah penyelesaiannya sangat membantu dalam memudahkan pemecahan masalah (Syamsi, 1995). Namun penelitian ini menunjukan bahwa kelima subjek sebelumnya belum pernah mengalami permasalahan yang sama, sehingga dalam pengambilan keputusan ini kelima subjek tidak memiliki dasar pengambilan berdasarkan pengalaman. 
5. Wewenang

Keputusan berdasarkan wewenang ini biasannya dilakukan oleh seseorang yang lebih tinggi kedudukannya terhadap orang yang rendah kedudukannya. Sehingga dalam pengambilan keputusan kelima subjek dalam penelitian ini tidak memiliki dasar pengambilan keputusan berdasakan wewenang karena keputusan diambil secara bersama baik ayah maupun ibu.

Menurut Simon (dalam Fahmi, 2016) proses pengambilan keputusan berlangsung melalui empat tahap:

1. Intellegence, adalah proses pengumpulan informasi yang bertujuan mengidentifikasi masalah. Kelima subjek mencari informasi terkait permasalahan yang mereka hadapi.

"Iya saya mencari fakta kebenarane kepiye to mbak. Tapi tak gawe meneng mbak tonggo-tonggo bent ora do reti." (Subjek AS)

"....yo masalahe aku nikahne anak yo mergo kui mau to mbak...anak sudah....(mengisaratkan menggunakan gerakan tangan bahwa anak sudah hamil)" (Subjek AS)

“..aku golek informasi. Yo takok karo anakku kui mau seng ngetengi sopo ngono kui to mbak. Soale pas kui posisine usia kandungane yo wes lumayan mbak." (Subjek SI)

"Nek ngoten niku nggeh kulo pados kejelesane mbak, ternyata yo tenan anakku wis isi disik, yo pokok e aku takok mbak seng gawe anakku koyo ngono kui sopo, tak takokne neng anakku mbak." (Subjek F)

2. Design adalah proses perancangan solusi terhadap masalah. Dalam penelitian ini dapat diketahui bahwa subyek AS merancang solusi terlebih dahulu untuk menyelesaikan permasalahannya. AS berpikir untuk aborsi sebelum pengambilan keputusan menikahkan dini anak. Sedangkan keempat Subyek yang lain yaitu SI, T, SM dan F juga merancang solusi, yang mana solusi tersebut yaitu menikahkan anak.

"Ya pie ya mbak... awale berpikir arep di aborsi barang mbak... mergo aku isin mbak nek reti wong-wong anakku meteng disik...terus ibu e yo wes setuju yen arep dik aborsi kui mau.." (subjek AS)

"Ya merancang mbak. Solusi, rencanaku ya Cuma menikahkan itu saja." (Subjek T)

"Nganu mbak, yo ngrancang, rencanane yo nikahne anak mau." (Subjek SM) 
"Yo nek kui rencanaku yo mung kui mbak, nikahne anak kui mau mbak. Kadang kan enek wong seng mikir kanggo gugurne kandungane ngono yo mbak, nek kulo mboten mbak, kulo mboten arep nambahi doso mbak, nek gugurne ngono kui kan podo karo membunuh makhluk sing ora berdosa mbak." (Subjek F)

3. Choice, adalah tahap mengkaji kelebihan dan kekurangan dari berbagi macam alternatif yang ada dan memilih yang terbaik. Dalam mengkaji kekurangan dan kelebihan dari alternatif yang telah ditentukan Subyek AS sebelum memilih untuk menikahkan anak subyek AS pernah berpikir untuk aborsi, namun setelah mengetahu dampak dari aborsi tersebut AS berubah pikiran dan memilih menikahkan anak. Dari kelima subyek penelitian ini mengatakan bahwa bagi mereka menikahkan anak merupakan solusi terbaik.

“... awale berpikir arep di aborsi barang mbak... mergo aku isin mbak nek reti wong-wong anakku meteng disik...terus ibu e yo wes setuju yen arep dik aborsi kui mau..tapi ora sido mbak.. aku terus berubah pikiran...soale aku ngerti mbak soko wong seng wes tau aborsi, terus kedepane ora isoh ndwe anak teko seprene mbak.. aku wedi nek anakku koyo ngono kui. Makane terus aku njupuk keputusan kanggo nikahne anak kui mau mbak." (Subjek AS)

4. Implementasi, adalah tahap pengambilan keputusan dan melaksanakakannya. Setelah kelima subyek memilih solusi yang terbaik untuk menyelesaikan permasalahannya. Tahap selanjutnya yaitu pengambilan keputusan, yang mana pengambilan keputusan kelima subyek dalam penelitian ini adalah menikahkan anak meskipun anak dibawah umur.

"Yo... menurutku kui seng paling apik mbak daripada di aborsi kui mau mbak. Terus anakku yo bent bertanggung jawab barang karo perbuatan seng wes dek lakokne." (Subjek AS)

"Iyo to mbak.. menurutku nikahne anak kui solusi seng paling apik mbak. wong yo kedepane kanggo kebahagiane anak kok mbak." (Subjek SM)

"Ya... saya anggap solusi terbaik daripada nanti anak saya mengandung tanpa adanya suami. Terus saya ngambil keputusan menikahkan itu saya takut nek anak lari, atau berbuat yang engga-engga. Itu loh mbak saya mengambil keputusan itu terbaik menurut saya." (Subjek T)

Kemudian, setelah pengambilan keputusan subjek melaksanakan keputusan yang dipilihnya. Hal tersebut digambarkan oleh kelima subjek bahwa acara pernikahan anak mereka berjalan dengan lancar. Jadi dapat dikatakan bahwa mereka telah melaksanakan keputusan yang mereka ambil. 
“Emmmm... iyo Alhamdulillah mbak berjalan baik, lancar." (Subjek SI)

\section{KESIMPULAN}

Orang tua yang dihadapkan dalam permasalahan anak hamil diluar nikah mau tidak mau harus mengambil sebuah keputusan. Pengambilan keputusan adalah pemilihan satu dari beberapa solusi atau alternatif terbaik guna menyelesaikan suatu permasalahan. Dalam pengambilan keputusan orang tua memiliki dasar pengambilan keputusan yaitu intuisi, rasional dan fakta.

Kemudian proses pengambilan keputusan yang dilakukan oleh orang tua untuk menyelesaikan permasalahan anak hamil diluar nikah yaitu orang tua ada yang berencana ingin melakukan aborsi, namun setelah mengetahui dampak dari keputusan tersebut berubah pikiran dan memilih untuk menikahkan anak. Bagi orang tua menikahkan anak merupakan solusi atau alternatif terbaik guna menyelesaikan permasalahan anak hamil diluar nikah. Orang tua terpaksa menikahkan anak guna menutupi aib keluarga karena mereka tidak ingin anaknya hamil tanpa adanya suami dan orang tua ingin anak bertanggung jawab atas perbuatan yang sudah dilakukan.

\section{SARAN}

1. Kepada orang tua diharapkan lebih bisa memperhatikan pergaulan anak, terutama untuk orang tua yang memiliki anak diusia remaja.

2. Kepada orang tua yang menikahkan dini anak diharapkan dapat membimbing anak untuk menjaga rumah tangganya, karena anak pada usia tersebut secara pengetahuan dan pengalaman belum cukup untuk hidup berumah tangga.

3. Bidan Desa atau tokoh masyarakat perlu memberikan sosialisasi tentang kesehatan reproduksi kepada remaja sejak SMP untuk mencegah kejadian hamil diluar nikah pada remaja yang lain.

4. Bagi peneliti selanjutnya karena penelitian ini memiliki beberapa keterbatasan, maka dari itu untuk penelitian selanjutnya dalam kasus yang sama diharapkan selain meneliti subjek orang tua yang mengambil keputusan menikahkan anak diusia dini alangkah lebih baik anak yang menikah dini juga diteliti supaya lebih menarik.

\section{DAFTAR PUSTAKA}

Amalia, Elisa Happy. (2015). Faktor-Faktor yang Mempengaruhi Terjadinya Kehamilan Tidak Diinginkan Pada Remaja (Studi Kasus Remaja di Kota Madiun). Skripsi Universitas Negeri Semarang. 
Aprianti dkk. (2018). Fenomena Pernikahan Dini Membuat Orang Tua dan Remaja Tidak Takut Mengalami Kehamilan Tidak Diinginkan. Jurnal Promosi Kesehatan Indonesia, 13(1), 61-73.

Fahmi, Irham. (2016). Teori dan Teknik Pengambilan Keputusan. Depok: Rajawali Pers.

Hastuti, Puji \& Fajaria Nur Aini. (2016). Gambaran Terjadinya Pernikahan Dini Akibat Pergaulan Bebas. Jurnal Riset Kesehatan, 5(1), 11-13.

Junaidi,. Syahida N.P., \& Nuraini. (2019). Fenomena Pernikahan Dini Di Desa Loloan Kecamatan Bayan Kabupaten Lombok Utara. Jurnal Ilmu Administrasi Publik, 7(1), 34-43.

Kanella, A.W., Anggi Napida A., \& Suparman. (2017). Faktor-Faktor yang Berhubungan dengan Pernikahan Dini pada Wanita. Jurnal of Nursing and Midwifery, 5(1), 68-75.

Marantika, Roike Yosi. (2015). Dampak Hamil Di Luar Nikah Terhadap Keharmonisan Rumah Tangga. Skripsi Universitas Islam Negeri Sunan Kalijaga Yogyakarta.

Mubasyaroh. (2016). Analisis Faktor Penyebab Pernikahan Dini dan Dampaknya Bagi Pelakunya. Jurnal Pemikiran dan Penelitian Sosial Keagamaan, 7(2), 385-411.

Murcahya, Ardiyanto. (2010). Dinamika Psikologis Pengambilan Keputusan Untuk Menikah Dini. Skripsi Universitas Muhammadiyah Surakarta.

Raco. (2010). Metode Penelitian Kualitatif. Jakarta: Grasindo.

Rahmawati, Alifah \& Friska Realita. (2017). Pengetahuan dan Perilaku Seksual Pranikah. Jurnal Komunikasi Kesehatan, VIII(1), 45-61.

Sari, Putri Perwita \& Dinie Ratri Desiningrum. (2017). Pengalaman Berkeluarga Pada Wanita yang Menjalani Married By Accident. Jurnal Empati, 6(1), 338345.

Suhaida, Siti, dkk. (2018). Pergaulan Bebas Di Kalangan Pelajar. Neo Societal, 3(2), 425-432.

Syamsi, Ibnu. (1995). Pengambilan Keputusan dan Sistem Informasi. Jakarta: Bumi Aksara.

Tyas, Aprilia K.S., \& Siti Hafsah Budi Argianti. (2018). Pengambilan Keputusan Menikah Dini Pada Remaja Putri Di Kecamatan Sukoharjo Ngaglik. Jurnal Spirits, 8(2), 79-93.

Yanti., Hamidah., \& Wiwita. (2018). Analisis Faktor Penyebab dan Dampak Pernikahan Dini Di Kecamatan Kandis Kabupaten Siak. Jurnal Ibu dan Anak, 6(2) , 96-103. 